\title{
Leaf anatomy of Quercus macranthera subsp. syspirensis (K.Koch) Menitsky
}

\author{
Muhammed Mesud HÜRKUL *1, Şeyda YAYLA ${ }^{1}$ \\ ORCID: 0000-0002-9241-2496; 0000-0002-3678-6506
}

${ }^{1}$ Ankara University, Faculty of Pharmacy, Department of Pharmaceutical Botany,06560 Ankara, Turkey

\begin{abstract}
The genus Quercus L. (Fagaceae) is represented by 461 species worldwide. Its distribution ranges from the temperate northern hemisphere to Malaysia and Colombia. Quercus bark is rich in tannins and is used as an astringent. Quercus macranthera subsp. syspirensis (K.Koch) Menitsky is endemic to Turkey and is known as "ispir meşesi". The plant is a small deciduous tree up to $7 \mathrm{~m}$ tall. Leaves obovate with 5-9 short lobes, stipules filiform, primary veins 6-10 and petiole $5-20 \mathrm{~mm}$.

The plant material was collected from Kastamonu-Araç (Turkey). A voucher specimen was deposited in the Ankara University Faculty of Pharmacy Herbarium (AEF). The samples for anatomical studies were protected in $70 \%$ alcohol. The transverse and surface sections were cut by hand with razor blade into microscopic preparat form. The Sartur solution was used in microscopic examinations. Leica DM 4000B microscope was used for anatomical analysis and micro photographing.

According to the results of the anatomical study, the leaf is bifacial. Numerous stellate hairs are found on the upper and lower epidermis. Stomata are located only on the lower epidermis. The leaf and petiole contain solitary crystals. The petiole is characterized by a numerous stellate hairs. The sclerenchymatous tissue surrounds the vascular bundles in the form of a ring.
\end{abstract}

Keywords: Quercus macranthera subsp. syspirensis, Fagaceae, leaf, anatomy, endemic

\section{Quercus macranthera subsp. syspirensis (K.Koch) Menitsky'in yaprak anatomisi}

\section{Özet}

Quercus L. (Fagaceae) cinsi dünya genelinde 461 tür ile temsil edilir. Yayılıș alanları 1lıman kuzey yarımküreden Malezya ve Kolombiya'ya kadardır. Quercus gövde kabukları tanen bakımından zengindir ve astrenjan olarak kullanılır. Quercus macranthera subsp. syspirensis (K.Koch) Menitsky Türkiye için endemik olup "ispir meşesi" olarak bilinir. Bitki 7 m boylanan, yaprak döken küçük ağaçtır. Yapraklar 5-9 kısa loblu, obovat, filiform stipulalı, 6-10 primer damarlı ve 5-20 mm uzunluğunda yaprak saplıdır.

Bitki materyali Kastamonu-Araç (Türkiye)'tan toplandı. Bir örneği Ankara Üniversitesi Eczacılık Fakültesi Herbaryumu (AEF)'na kaydedildi. Anatomik çalışmalar için numuneler \%70 alkolde korundu. Enine ve yüzey kesitleri el ile jilet kullanılarak mikroskobik preparat haline getirildi. Mikroskobik incelemelerde Sartur solüsyonu kullanıldı. Anatomik analiz ve mikro fotoğraflama için Leica DM 4000B mikroskobu kullanıldı.

Anatomik çalışma sonucuna göre, yaprak bifasiyaldir. Üst ve alt epidermada çok sayıda yıldız tüy bulunur. Stomalar sadece alt epidermada yer alır. Yaprak ve yaprak sapı kristaller içerir. Yaprak sapı çok sayıda yıldız tüy ile karakterizedir. İletim demetlerini sklerenkimatik doku halka şeklinde sarmıştır.

Anahtar kelimeler: Quercus macranthera subsp. syspirensis, Fagaceae, yaprak, anatomi, endemik

\section{Introduction}

\footnotetext{
* Corresponding author / Haberleşmeden sorumlu yazar: +905305917304; Fax.: +903122131081; E-mail: huerkulmm@ gmail.com

(c) Copyright 2021 by Biological Diversity and Conservation $\quad$ Geliş tarihi: 15.07.2021; Yayın tarihi: 15.12.2021 BioDiCon. 983-150721
} 
Fagaceae Dumort. is a family of evergreen or deciduous trees or shrubs [1]. The family includes 8 accepted genera (Castanea Mill., Castanopsis (D.Don) Spach, Chrysolepis Hjelmq., Fagus L., Lithocarpus Blume, Notholithocarpus Manos, Cannon \& S.H.Oh, Quercus L., Trigonobalanus Forman) [2]. The genus Quercus is represented by 461 species worldwide, its distribution ranges from the temperate northern hemisphere to Malaysia and Colombia [2]. Quercus genus consists of deciduous or evergreen trees, rarely shrubs; the leaves are arranged subsessile or petiolate, penninerved, serrate, dentate, pinnatifid or lobed; fruit a nut (acorn), subglobose to oblong or cylindrical, surrounded at base by cupule; pericarp thin or thick, endocarp glabrous or pubescent [1].

Oak bark is rich in tannins and is used as an astringent [3]. Quercus species also known to contain (-)epicatechin, (-)-epigallocatechin, (+)-catechin, (+)-gallocatechin, gallic acid, caffeic acid, ferulic acid, ellagic acid [4-9] and used traditionally in the treatment of dermatitis, burns, hemorrhoids, abscesses, ulcers and toothache [10-14]. Quercus species are medically important and show antibacterial, anticancer, gastroprotective, antiviral, cardioprotective and hepatoprotective activity [15-24]. In Turkey, Quercus species are traditionally used in the treatment of diabetes, wounds, respiratory diseases, diarrhea, obesity and fungus [25-33].

32 Quercus taxa (5 endemic) grow naturally in Turkey, Quercus macranthera subsp. syspirensis (K.Koch) Menitsky is endemic to Turkey and is known as "ispir meşesi" [34]. The plant is a small deciduous tree up to $7 \mathrm{~m}$ tall; leaves obovate with 5-9 short lobes, stipules filiform, primary veins 6-10 and petiole 5-20 mm [1]. Revealing the anatomical features and differences of organs is of great importance in taxonomically distinguishing species from each other. There is no comprehensive anatomical study on the $Q$. macranthera subsp. syspirensis until now. In this study, the anatomical features of $Q$. macranthera subsp. syspirensis leaf and petiole were examined in detail.

\section{Materials and methods}

The plant material was collected from Araç (Kastamonu/Turkey) in 2020 and described by M. Mesud Hürkul. A voucher specimen was deposited in the Ankara University Faculty of Pharmacy Herbarium (AEF 30737) in Turkey. The samples for anatomical studies were protected in $70 \%$ alcohol. The transverse and surface sections were cut by hand with razor blade into microscopic preparation form. The Sartur solution [35] was used in microscopic examinations. Leica DM 4000B microscope was used for anatomical analysis and micro photographing.

\section{Results}

In the transverse section of the leaf, the midrib is highly domed in the abaxial side. The upper epidermis layer consists of square-oval cells and is surrounded by a thick cuticle layer. The outer walls of upper epidermal cells are sinuous. The base of the epidermis layer is filled with 5-10 rows of parenchymatous cells. In the midrib, the vascular bundle is completely surrounded by sclerenchymatous cells in a ring. The xylem and phloem is arc-type arranged but tend to a circle form. The abaxial side of vascular bundle in the midrib is filled with 8-15 rows of parenchymatous cells. The lower epidermal cells are oval-square shaped, crushed and smaller than the upper epidermal cells. The lower epidermis is covered with a thick cuticle. Both the upper and lower epidermis include numerous stellate hairs. The midrib contains sparse solitary crystals (Figure 1).

The transverse section of leaf lamina showed that the leaf was bifacial. The upper epidermis layer consists of a single layered of square-rectangular epidermal cells. The epidermis layer covered with thick cuticle and many stellate hairs. The mesophyll is characterized by 3 rows of longitudinal elongated, starch containing palisade parenchyma and 3-8 rows of spongy parenchyma. The lower epidermis layer consists of square cells and the lower epidermal cells are much smaller than the upper cells. The lower epidermis layer covered by thick cuticle layer and numerous stellate hairs. The mesophyll contains sparse solitary crystals (Figure 2-a). The leaf surface sections showed stomata only in the lower epidermis. The stomata is surrounded by 5 subsidiary epidermal cells. Both upper and lower epidermis covered with numerous stellate hairs (Figure 2-b,2-c).

The transverse section of the petiole is a disc shape. Numerous stellate hairs cover the surface. The epidermis consists of a single layer, oval cells and is covered by a thick cuticle. The vascular bundle, surrounded by sclerenchymatous tissue, contains xylem and phloem in a ring form. Between the epidermis and the vascular bundle, 815 rows of parenchymatous tissue are included. The parenchymatous tissue contains numerous solitary crystals (Figure 3). 

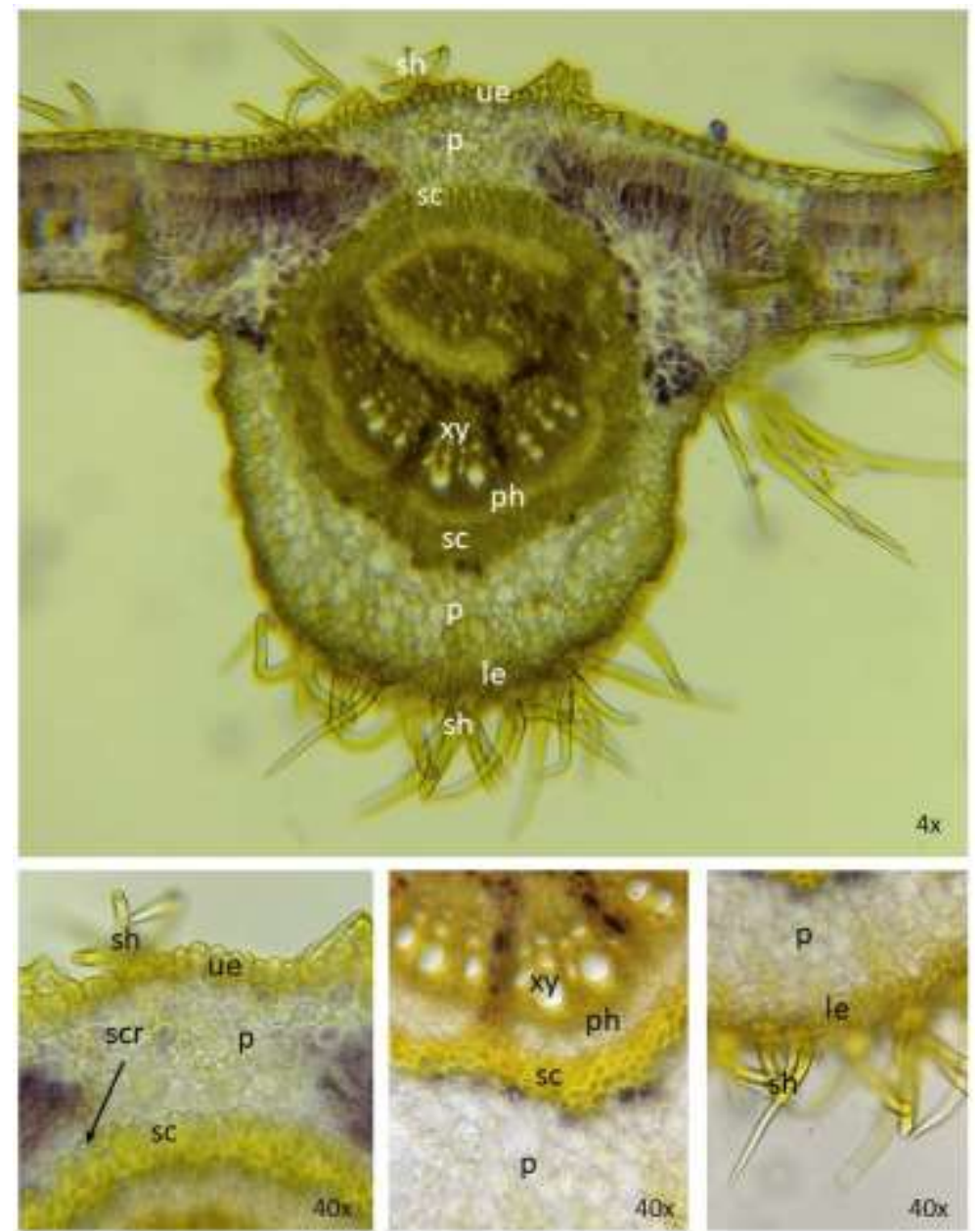

Figure 1. The transverse section of the midrib (le: lower epidermis, p: parenchyma, ph: phloem, sc: sclerenchyma, scr: solitary crystal, sh: stellate hair, ue: upper epidermis, xy: xylem)
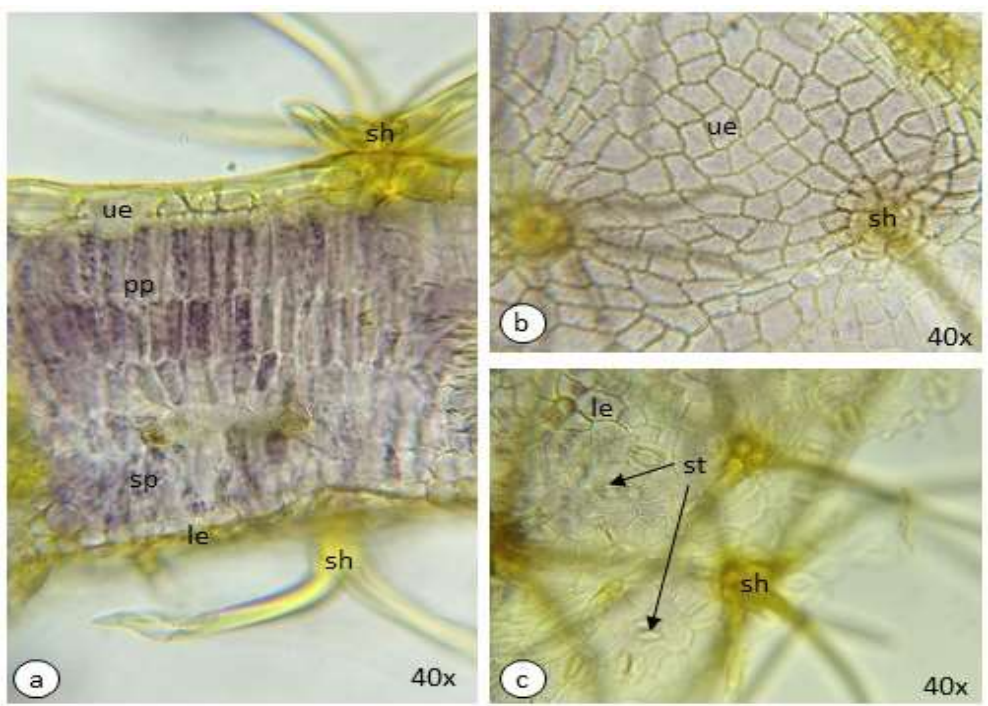

Figure 2. The anatomical features of leaf lamina (a: transverse section of lamina, b: surface section of upper epidermis, c: surface section of lower epidermis, le: lower epidermis, pp: palisade parenchyma, sh: stellate hair, sp: spongy parenchyma, st: stomata, ue: upper epidermis) 


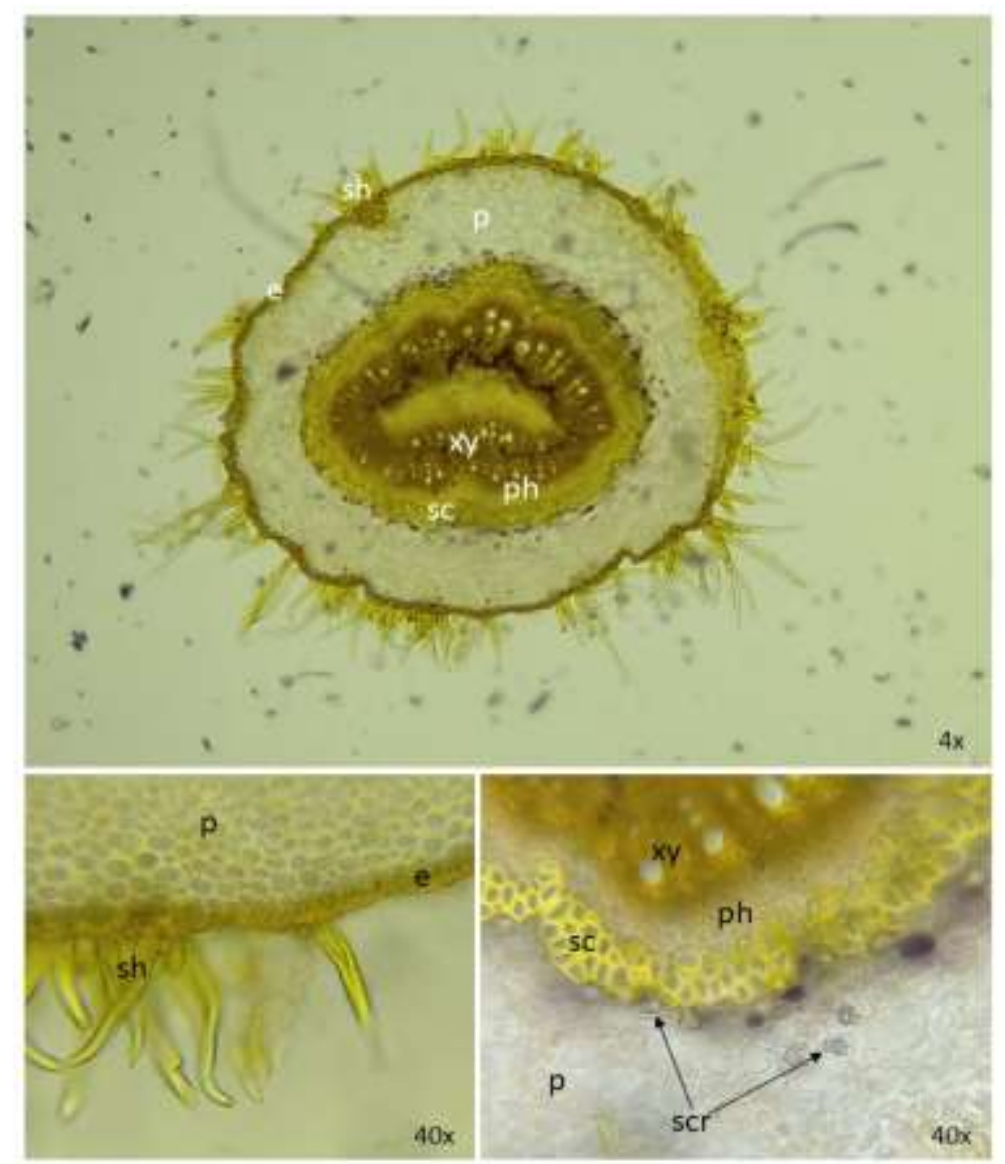

Figure 3. The transverse section of petiole (e: epidermis, p: parenchyma, ph: phloem, sc: sclerenchyma, scr: solitary crystal, sh: stellate hair, xy: xylem)

\section{Conclusions and discussion}

Quercus species are traditionally used in folk medicine [10-14, 25-33]. The correctly describe and determine of plants is very important, which are herbal medicine candidates and continue to be used in traditional folk medicine. Microscopic analysis of the anatomical structures of plants could provide useful information for the taxonomic classification. Light microscopy analysis is a common and effective method for the identification of medicinal plants [36].

In this study, leaf and petiole anatomy of Quercus macranthera subsp. syspirensis was studied in detail. In the leaf transverse section, the midrib is domed abaxially, the epidermal layer is covered with a thick cuticle and numerous stellate hairs. The vascular bundle is arc-shape arranged, mostly tend to ring shape and confined by sclerenchymatous tissue. The parenchymatous tissue covers between the epidermis tissue and the vascular bundle. The parenchyma includes sparse solitary crystals. In the lamina transverse section, the upper epidermis cells are clearly larger than the lower epidermal cells. The epidermis layer is covered with a thick cuticle and carries many stellate hairs. The mesophyll is characterized by 3 rows of palisade parenchyma and 3-8 rows of spongy parenchyma, additionally contains abundant starch grains. In the leaf surface sections, the stomata are located in the lower epidermis with 5 subsidiary cells. The upper epidermis is free of the stomata. Numerous stellate hairs were observed on both surfaces. The petiole is discshaped in the transverse section. The monolayer epidermis is surrounded by a thick cuticle and contains numerous stellate hairs. The vascular bundle surrounded by sclerenchyma is embedded in parenchymatous cells. The petiole contains relatively denser solitary crystals than leaf.

According to the previous study [37] on the anatomical structures of the Fagaceae family, Quercus leaves include a variety of hair types, such as simple-unicellular, stellate hairs; in several species of Quercus has uniseriate and/or capitate glands; epidermis composed of cells with straight or sinuous anticlinal walls, sometimes tend to be papillose on the lower surface; the stomata located on the lower surface as ranunculaceous; the vascular bundle is surrounded by arcs of sclerenchyma; the vascular system is consisting of a continuous or dissected cylinder. In our study, stellate hairs were densely detected both on the leaf and on the petiole, and stomata were observed in the lower epidermis. Simple-unicellular hairs and glandular hairs, noted in the previous study [37], were not observed. The 
epidermal cells with papilla not detected in our study. According to our study, the sclerenchymatous tissue surrounding the vascular bundles is not in the form of an arc, but in the form of a ring.

* This study was presented as an oral presentation at "Adlyaman 1. Uluslararası Fen ve Uygulamalı Bilimler Kongresi [Adıyaman 1st International Sciences and Applied Sciences Congress] (13-14 July 2021, Gölbaşl, Adıyaman, Turkey)”.

\section{References}

[1] Davis, P. H. (1982). Flora of Turkey and the East Aegean Islands. Edinburgh, UK: Edinburgh University Press.

[2] POWO (2021). "Plants of the World Online. Facilitated by the Royal Botanic Gardens, Kew. Published on the Internet; http://www.plantsoftheworldonline.org (Accessed 10.07.2021).

[3] Evans, W. (2002). Trease and Evans pharmacognosy (15th ed.). WB Saunders.

[4] Buche, G., Colas, C., Fougère, L., Giordanengo, T., \& Destandau, E. (2020). Untargeted UHPLC-Q-TOF-HRMS based determination of discrimating compounds for oak species Quercus robur L. and Quercus petraea Liebl. identification. Phytochemical Analysis. https://doi.org/10.1002/pca.3013

[5] Marinov, M. G., Dimitrova, E. D., \& Puech, J. L. (1997). Kinetics of ellagitannin extraction from oak wood using white wine. Journal of Wine Research, 8(1), 29-40. https://doi.org/10.1080/09571269708718095

[6] Perez, A. J., Pecio, Ł., Kowalczyk, M., Kontek, R., Gajek, G., Stopinsek, L., ... \& Stochmal, A. (2017). Triterpenoid components from oak heartwood (Quercus robur) and their potential health benefits. Journal of agricultural and food chemistry, 65(23), 4611-4623. https://doi.org/10.1021/acs.jafc.7b01396

[7] Ricci, A., Parpinello, G. P., Palma, A. S., Teslić, N., Brilli, C., Pizzi, A., \& Versari, A. (2017). Analytical profiling of food-grade extracts from grape (Vitis vinifera sp.) seeds and skins, green tea (Camellia sinensis) leaves and Limousin oak (Quercus robur) heartwood using MALDI-TOF-MS, ICP-MS and spectrophotometric methods. Journal of Food Composition and Analysis, 59, 95-104. https://doi.org/10.1016/j.jfca.2017.01.014

[8] Şöhretoğlu, D., Sakar, M. K. (2004). Polyphenolic constituents and biological activities of Quercus species. Journal of Faculty of Pharmacy of Ankara University, 33(3), 183-215.

[9] Vivas, N., Nonier, M. F., de Gaulejac, N. V., \& de Boissel, I. P. (2004). Occurrence and partial characterization of polymeric ellagitannins in Quercus petraea Liebl. and Q. robur L. wood. Comptes Rendus Chimie, 7(8-9), 945-954. https://doi.org/10.1016/j.crci.2004.06.004

[10] Carrió, E., \& Vallès, J. (2012). Ethnobotany of medicinal plants used in eastern Mallorca (Balearic Islands, $\begin{array}{lllll}\text { Mediterranean Sea). Journal of } & \text { Ethnopharmacology, } & 141(3), & 1021-1040 .\end{array}$ https://doi.org/10.1016/j.jep.2012.03.049

[11] Gilca, M., Tiplica, G. S., \& Salavastru, C. M. (2018). Traditional and ethnobotanical dermatology practices in Romania and other Eastern European countries. Clinics in dermatology, 36(3), 338-352. https://doi.org/10.1016/j.clindermatol.2018.03.008

[12] Leporatti, M. L., \& Ivancheva, S. (2003). Preliminary comparative analysis of medicinal plants used in the traditional medicine of Bulgaria and Italy. Journal of ethnopharmacology, 87(2-3), $123-142$. https://doi.org/10.1016/S0378-8741(03)00047-3

[13] Sõukand, R., \& Pieroni, A. (2016). The importance of a border: medical, veterinary, and wild food ethnobotany of the Hutsuls living on the Romanian and Ukrainian sides of Bukovina. Journal of ethnopharmacology, 185, 17-40. https://doi.org/10.1016/j.jep.2016.03.009

[14] Šarić-Kundalić, B., Dobeš, C., Klatte-Asselmeyer, V., \& Saukel, J. (2010). Ethnobotanical study on medicinal use of wild and cultivated plants in middle, south and west Bosnia and Herzegovina. Journal of Ethnopharmacology, 131(1), 33-55. https://doi.org/10.1016/j.jep.2010.05.061

[15] Alkofahi, A., \& Atta, A. H. (1999). Pharmacological screening of the anti-ulcerogenic effects of some Jordanian medicinal plants in rats. Journal of Ethnopharmacology, 67(3), 341-345. https://doi.org/10.1016/S03788741(98)00126-3

[16] Andrenšek, S., Simonovska, B., Vovk, I., Fyhrquist, P., Vuorela, H., \& Vuorela, P. (2004). Antimicrobial and antioxidative enrichment of oak (Quercus robur) bark by rotation planar extraction using ExtraChrom ${ }^{\circledR}$. International Journal of Food Microbiology, 92(2), 181-187. https://doi.org/10.1016/j.ijfoodmicro.2003.09.009

[17] Berahou, A., Auhmani, A., Fdil, N., Benharref, A., Jana, M., \& Gadhi, C. A. (2007). Antibacterial activity of Quercus ilex bark's extracts. Journal of Ethnopharmacology, 112(3), $426-429$. https://doi.org/10.1016/j.jep.2007.03.032

[18] Deryabin, D. G., \& Tolmacheva, A. A. (2015). Antibacterial and anti-quorum sensing molecular composition derived from Quercus cortex (Oak bark) extract. Molecules, 20(9), 17093-17108. https://doi.org/10.3390/molecules200917093

[19] Frédérich, M., Marcowycz, A., Cieckiewicz, E., Mégalizzi, V., Angenot, L., \& Kiss, R. (2009). In vitro anticancer potential of tree extracts from the Walloon Region forest. Planta medica, 75(15), 1634-1637. https://doi.org/10.1055/s-0029-1185867 
[20] Gharzouli, K., Khennouf, S., Amira, S., \& Gharzouli, A. (1999). Effects of aqueous extracts from Quercus ilex L. root bark, Punica granatum L. fruit peel and Artemisia herba-alba Asso leaves on ethanol-induced gastric damage in rats. Phytotherapy Research: An International Journal Devoted to Pharmacological and Toxicological Evaluation of Natural Product Derivatives, 13(1), 42-45. https://doi.org/10.1002/(SICI)10991573(199902)13:1<42::AID-PTR383>3.0.CO;2-2

[21] Güllüce, M., Adigüzel, A., Öğütçü, H., Şengül, M., Karaman, I., \& Şahin, F. (2004). Antimicrobial effects of Quercus ilex L. extract. Phytotherapy Research: An International Journal Devoted to Pharmacological and Toxicological Evaluation of Natural Product Derivatives, 18(3), 208-211. https://doi.org/10.1002/ptr.1419

[22] Jassim, S. A. A., \& Naji, M. A. (2003). Novel antiviral agents: a medicinal plant perspective. Journal of applied microbiology, 95(3), 412-427. https://doi.org/10.1046/j.1365-2672.2003.02026.x

[23] Khennouf, S., Benabdallah, H., Gharzouli, K., Amira, S., Ito, H., Kim, T. H., ... \& Gharzouli, A. (2003). Effect of tannins from Quercus suber and Quercus coccifera leaves on ethanol-induced gastric lesions in mice. Journal of agricultural and food chemistry, 51(5), 1469-1473. https://doi.org/10.1021/jf020808y

[24] Panchal, S. K., \& Brown, L. (2013). Cardioprotective and hepatoprotective effects of ellagitannins from European oak bark (Quercus petraea L.) extract in rats. European journal of nutrition, 52(1), 397-408. https://doi.org/10.1007/s00394-011-0277-1

[25] Bulut, G., Haznedaroğlu, M. Z., Doğan, A., Koyu, H., \& Tuzlacı, E. (2017). An ethnobotanical study of medicinal plants in Acipayam (Denizli-Turkey). Journal of Herbal Medicine, 10, 64-81. https://doi.org/10.1016/j.hermed.2017.08.001

[26] Cakilcioglu, U., \& Turkoglu, I. (2010). An ethnobotanical survey of medicinal plants in Sivrice (Elazı̆̆-Turkey). Journal of Ethnopharmacology, 132(1), 165-175. https://doi.org/10.1016/j.jep.2010.08.017

[27] Senkardes, I., \& Tuzlaci, E. (2014). Some Ethnobotanical Notes from Gundogmus District (Antalya/Turkey). Clinical and Experimental Health Sciences, 4(2), 63.

[28] Sargin, S. A. (2021). Plants used against obesity in Turkish folk medicine: A review. Journal of Ethnopharmacology, 113841. https://doi.org/10.1016/j.jep.2021.113841

[29] Sargın, S. A., Akçicek, E., \& Selvi, S. (2013). An ethnobotanical study of medicinal plants used by the local people of Alaşehir (Manisa) in Turkey. Journal of Ethnopharmacology, 150(3), 860-874. https://doi.org/10.1016/j.jep.2013.09.040

[30] Polat, R., Cakilcioglu, U., \& Sat1l, F. (2013). Traditional uses of medicinal plants in Solhan (Bingöl-Turkey). Journal of Ethnopharmacology, 148(3), 951-963. https://doi.org/10.1016/j.jep.2013.05.050

[31] Sargin, S. A., Selvi, S., \& Büyükcengiz, M. (2015). Ethnomedicinal plants of Aydıncık district of Mersin, Turkey. Journal of Ethnopharmacology, 174, 200-216. https://doi.org/10.1016/j.jep.2015.08.008

[32] Kültür, Ş. (2007). Medicinal plants used in Kırklareli province (Turkey). Journal of Ethnopharmacology, 111(2), 341-364. https://doi.org/10.1016/j.jep.2006.11.035

[33] Sezik, E., Yeşilada, E., Honda, G., Takaishi, Y., Takeda, Y., \& Tanaka, T. (2001). Traditional medicine in Turkey X. Folk medicine in central Anatolia. Journal of Ethnopharmacology, 75(2-3), 95-115. https://doi.org/10.1016/S0378-8741(00)00399-8

[34] Güner, A., Aslan, S., Ekim, T., Vural, M., Babaç, M. T. (2012). Türkiye Bitkileri Listesi (Damarlı Bitkiler). Nezahat Gökyigit Botanik Bahçesi Yayınları, Flora Dizisi I.

[35] Türk Farmakopesi (2017). Türk Farmakopesi, genel monograflar I. Ankara, Türkiye: T.C. Sağlık Bakanlığ1.

[36] Alamgir, A. N. M. (2017). Pharmacognostical Botany: Classification of medicinal and aromatic plants (MAPs), botanical taxonomy, morphology, and anatomy of drug plants. In K. D., Rainsford (Eds.), Therapeutic use of medicinal plants and their extracts (Vol. 1, pp.177-293). Springer International Publishing AG.

[37] Metcalfe, C. R., \& Chalk, L. (1965). Anatomy of dicotyledones. (Vol. 2). Oxford, UK: Clarendon Press. 